This article was downloaded by: [University of Sussex Library]

On: 25 March 2015, At: 09:41

Publisher: Routledge

Informa Ltd Registered in England and Wales Registered Number: 1072954

Registered office: Mortimer House, 37-41 Mortimer Street, London W1T

3J H, UK

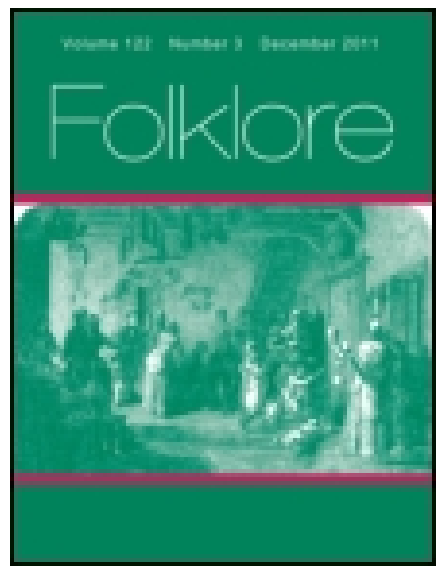

\title{
Folklore
}

Publication details, including instructions for authors and subscription information:

http:// www. tandfonline.com/loi/ rfol20

\section{The Roman Van Walewein (Gawain)}

W. P. Ker

Published online: 14 Feb 2012.

To cite this article: W. P. Ker (1894) The Roman Van Walewein (Gawain), Folklore, 5:2, 121-127, DOI: 10.1080/ 0015587X. 1894.9720213

To link to this article: http:// dx. doi. org/ 10.1080/0015587X.1894.9720213

\section{PLEASE SCROLL DOWN FOR ARTICLE}

Taylor \& Francis makes every effort to ensure the accuracy of all the information (the "Content") contained in the publications on our platform. However, Taylor \& Francis, our agents, and our licensors make no representations or warranties whatsoever as to the accuracy, completeness, or suitability for any purpose of the Content. Any opinions and views expressed in this publication are the opinions and views of the authors, and are not the views of or endorsed by Taylor \& Francis. The accuracy of the Content should not be relied upon and should be independently verified with primary sources of information. Taylor and Francis shall not be liable for any losses, actions, claims, proceedings, demands, costs, expenses, damages, and other liabilities whatsoever or howsoever caused arising directly or indirectly in connection with, in relation to or arising out of the use of the Content.

This article may be used for research, teaching, and private study purposes. Any substantial or systematic reproduction, redistribution, reselling, loan, sub-licensing, systematic supply, or distribution in any form to anyone is 
expressly forbidden. Terms $\&$ Conditions of access and use can be found at http://www.tandfonline.com/page/terms-and-conditions 


\section{THE ROMAN VAN WALEWEIN (GAWAIN).}

BY PROFESSOR W. P. KER.

The Roman van Walewein, ed. A. Jonckbloet, Leiden, 1846 (cf. Gaston Paris, Fist. litt. de la France, xxx), is the work of two authors, Penninc and Pieter Vostaert, the first of whom, at the beginning, seems to profess independence of a French orginal, while the second inconsistently refers to "the French book" (die walsce tale, l. II, I41) from which the story is taken. The date is undetermined; there may have been some interval between the first and the second author (Dr. Jan te Winkel, Geschiedenis der nederlandsche Letterkunde, i, p. 179). The manuscript (1. 11,201) is dated 1350.

The story (analysed by M. Gaston Paris, l.c.) is interesting as a rare example of an Arthurian romance which follows throughout; with little digression, though considerable redundancy, the lines of a popular story. In other romances there is plenty of matter analogous to that of the fairy tales; but it would be difficult to find another which corresponds so closely in its main plot from beginning to "nd with that of a common popular story. The story of "Walewein", told in I I,200 lines, is the story of Grimm's "Golden Bird" and Campbell's "Mac Iain Direach", a quest for one marvellous thing leading to the quest for another and another, till the series is wound up; with the Fox as travelling companion of the hero.

\section{WALEWEIN.}

At the court of Arthur there appears, one day, coming in by the window, a magical chessboard of gold and silver, ivory, and precious stones, which rests for a little and then flies away. Gawain sets out to follow the chessboard and bring it back to the king.

He goes on till he comes to a high mountain that seems to block his way, but it opens for him as he comes, and closes after him. Here, within the mountain, he has to fight with dragons (four young ones and their dam) before he can get to an opening on the other side. There he finds 
himself high up on the cliff, above a raging river; his good horse Gringalet carries him through.

Then he comes to the castle of King Wonder, the owner of the chessboard, who promises to give the chessboard if Gawain will bring him the sword of the rings from King Amoraen (or Amoris). The search for the sword is the next adventure. There are episodes on the way, of a common romantic kind (Gawain "does awayan ill custom", and takes part in a tournament on behalf of a luckless man), but these things do not interfere with the principal story: they are accretions, not complications.

King Amoris has his castle in Ravensten, an island in the sea. He will give up the sword to Gawain, if Gawain will win for him the Princess of the Garden of India ; meanwhile he lends the sword to Gawain for the journey.

The sword is one that knows its master, and of itself makes obeisance to Gawain.

There is an episode of some importance before Gawain comes to the castle of King Assentin, father of the Princess Ysabele, and to the Garden of India where is the Fountain of Youth. He mortally wounds a felon Red Knight, who prays Gawain to give him Christian burial. It is the grateful ghost of this dead man who afterwards helps Gawain out of trouble.

The castle of King Assentin, like those of Wonder and of the Lord of Ravensten, has water about it; but this is the burning water of Purgatory (Vaghevier, 5825), with the bridge of the sharp edge lying across it, and Gawain cannot get over. He comes to a pleasant garden close and lies down to rest. As he is asleep the master of the place comes home, the Fox Roges, a prince transformed by his wicked stepmother. The Fox explains to Gawain the nature of the river : it rises in Hell and falls into the leversee (5955), the dull water, where nothing moves. He shows Gawain the dingy birds that shoot into the river and come out white and clean (5840); they are the souls. Gawain is led by the Fox through a passage under the river into the castle. There 
are twelve circles about the castle, and moats between the walls, but Gawain is not kept back, though it takes him some time to fight through the successive guards.

The princess recognises him as the knight that has appeared to her in a dream; and Gawain, for the love of the princess, forgets his duty to the master of the sword, for whom he has undertaken the adventure. The knight and the princess are helped to escape by the ghost of the Red Knight, whose shrift was heard by Gawain, and the Fox comes with them. When they reach Ravensten they find that King Amoris (as M. Paris expresses it) "has had the good taste to die in the meantime". After some difficulties, including an unnecessary encounter with Sir Estor, the brother of Sir Lancelot, in the ordinary inconsiderate fashion of romances, they come to King Wonder, and there the conditions are fulfilled that restore the Fox to his proper shape. It is noted that there was a concomitant restoration of the stepmother, who had been changed into a toad by the sister of Roges.

So Gawain brings away the chessboard; and he, and the Princess, and Roges, and Assentin the father of the Princess, and the King of "Hisike", father of Roges, are all together at a high festival in the court of Arthur. Pieter Vostaert would willingly tell of the wedding of Gawain; but it appears that the authority of "the French book" was wanting.

The common features of the story are the search for rare things, one after another, and one for the sake of the other, in a series; with the help of the Fox.

In Walewein, the search is for the chessboard of King Wonder, the magic sword of King Amoris, and the Princess, the King's daughter of India. The Fox has no part in the first two adventures. In the third, the gratitude of the dead is brought in as'a miraculous agency: the incident does not appear in the simpler forms.

In Grimm's story the search is for the Golden Bird, the 
Golden Horse, and the Princess of the Golden Castle, and the Fox is employed throughout.

Mac Iain Direach is sent to look for the blue Falcon, and is helped by the Fox. The giant who owns the Falcon offers to give it for the White Glaive of Light of the Big Women of Jura. The Big Women of Jura ask for the bay. Filly of the King of Eirinn: the King of Eirinn sends Mac Iain Direach to bring him the daughter of the King of France as his bride. With the help of the Fox, Mac Iain Direach wins all for himself: the Falcon, the Sword, the Filly, and the King's daughter.

In another version, given by Campbell, i, p. 353, the Fox is brother of the Princess, as he is also in Grimm's story, and is restored at the end.

The comparative insignificance of the Fox in Walewein is easily explained by the discrepancy between the adventurer of fairy-tale, and the knight-errant of chivalrous romance. Gawain is more heavily armed; he has an inconvenient history of his own, a character to keep up; so also has Gringalet, his horse. The difficulty of turning a hero of fairy tales into a knight of romance is obvious wherever a comparison has to be made between the romances and the popular tales. What is remarkable about Walewein is that in spite of its length there is so little organic change in the simple economy of the märchen. The lines of the story are clear and well defined: the rules are observed, the unities of the fairytale, not those of the sophisticated romance of chivalry. Much is added, but what is added is not intruded; the additions can be taken away; there is very little distortion or vitiation of the system.

The story has some likeness to la Mule sans Frein (Méon, Nouveau Recueil, i; cf. G. Paris, Romania, xii), in which also the search for something mysterious leads Gawain the adventurer beyond the River of the Narrow Bridge. That strange story, with its wonderful description of the gladness brought by King Arthur's knight into the 
waste city, and the "carols" in the streets, is associated" with the story of a similar deliverance wrought by Lancelot beyond the Perilous Bridges, in the Land of Gorre, as it is told by Crestien de Troyes in his poem of Lancelot (Chevalier de la Charrette, 11. 3515 sq.; cf. Rhys, Celtic Heathendom, p. 354).

Gawain in that story has to pass through several strange regions in the search for the magic Bridle. A forest full of wild beasts; a valley of fiery serpents and scorpions, and stink, and cold wind; a flowery plain; and then the black river, with the sharp bridge ;

$$
\begin{aligned}
& \text { "et si vos di, sanz nule fable, } \\
& \text { que ce est li fluns un déable"; }
\end{aligned}
$$

then the whirling castle. ${ }^{1}$

In Walewein, while the entrance into the Land of the Dead is plainly indicated, by the description of the waters of Purgatory running in front of the castle of the third adventure, the earlier adventures imply, with more ambiguity, that the common world is left.behind when Gawain enters into the mountain, and finds himself, after the fight with the dragons, on the brink of a river which he has to cross in order to win the magical thing he is looking for. The second castle, with the sword in it, is an island; though the water crossed by Gawain (at low tide) is somewhat tamer than the sounds that Mac Iain Direach had to cross in his search for the Glaive of Light.

On the return, in Walewein, there is no borderland to be passed over; the way back is open, and the way through the mountain into the common world is not mentioned again. Is the passage under the water a prosaic invention of the Dutch romancer, or his original "French book"? Or is it

\footnotetext{
I It is worth noting that, besides the ordeal of beheading, common to this story with the English poem of Gawain and the Green Knight, and with the Irish story of the Feast of Bricriu (M. Gaston Paris, loc. cit.), the whirling castle is also common to this and to the Irish. Story (cf. Rhys, Arthurian Legend, Appendix, p. 392).
} 
a prosaic adaptation of the pont evage, the underwater bridge, that is known to Crestien in the Chevalier de la Charrette? Crestien himself seems hardly to have understood the fashion of this bridge, and makes little more of it than the "Irish bridge" of the popular gibe; i.e., a ford in deep water. Whereas, to rival the terrors of the Bridge of the Sword, it must have been originally a bridge through, and in, and made of, the water itself, a tunnel of water through the water, to which the adventurer had to commit himself.

In the second Gaelic version the Princess is the Sun Goddess (or Sunbeam? Campbell, ii, p. 357 n.), daughter of the King of the Gathering of Fionn. This would seem to connect the story with the myth of the quest for the Sunbright unknown maiden, oversea-the story of Frey and Gerd; of the Danish ballad of Child Svendal, as of its original the Fiolsvinnsmal; of Alfhild in Saxo (cf. Rydberg, Teutonic Mythology, p. I13); of Orendel and Bride, in the middle High-German poem; of Conall Gulban and his search for "Breast o' Light"; and of the King's Son of Ireland and the daughter of the King with the Red Cap, in Macdougall's Tales (Celtic Tradition, iji, p. I45). It is the same story that recurs again in Walewein: the princess recognises Gawain, as Svipdag is recognised by Menglad. Even if the story of the various minor quests, for the chessboard, or the blue bird, or the sword of light, have no necessary connexion with the myths of Alfhild or Menglad, which is the myth of Berecynthia (Hjalmar Falk, Martianus Capella og den nordiske Myto$\log i$, Aarbog for nord. Oldkyndighed, 1891), it was inevitable that the popular story of these adventures should come, in some of its aberrations, within the orbit of the oldest romance and most famous quest in the world-the story of the Princess at the World's End.

Perhaps the most interesting thing in Walewein is the proof it affords that it was possible to transpose a story of this sort into the form of a long romance, without essential 
alteration in the general scheme. Even in the shorter French tales, such as those of Marie de France, it would be hard to find as close an observance of the proportions of a common "fairy-story" as is to be found in the construction of the romance of Walewein.

I take advantage of the blank page to add a few notes to Prof. Kers interesting paper. In Prof. G. Stephens' monograph on the "grateful dead" incident (Sir Amadace, Cheapinghaven, 1860), the oldest of a Fre he cites is a middle thirteenth century Swedish translation ably assuch legend, the hero of which is Pippin. If, as may be reasontwelfth ored, the "Walewein" represents a French original of the late may be oarly thirteenth century, the present example is as old, and is the older. Moreover, it is here connected with a "task" story, as British case with most of the examples of the theme collected in the itish Isles.

The stepmother transformation (p. 123) is an interesting instance of the counterspell so characteristic of the Celtic folk-tale. As a rule, the "villain" is transformed at the end as a punishment. Prof. Ker's remarks on the rôle of the hero in folk-tales and in
romance are weighty. They afford another argument in favour of
the the contention: "the folk-tale underlies the romance, the romance does not originate the folk-tale".-A. N. 